REGULAR ARTICLE

\title{
POLICY FOR IMPROVING ADOPTION AND PROFITABILITY OF IRRIGATION IN BENIN
}

\author{
Gbêtondji Melaine Armel NONVIDE
}

\author{
Address: \\ Faculté des Sciences Economiques et de Gestion (FASEG), Université d'Abomey-Calavi (UAC), Benin, \\ E-mail: melainearmel@gmail.com
}

\begin{abstract}
Majority of the irrigation schemes developed in Benin failed upon the withdrawal of foreign partners in 1980s, and these schemes were abandoned by farmers. The 2008 food crisis and the new challenge of climate change and variability have renewed Benin government interest to invest in irrigation development to achieve food security. This article explores the policies needed for such investments to be successful and improve adoption of irrigation and farmers' profitability using a case study from the rice irrigation scheme of Malanville, Benin. Results indicate that irrigated rice farming is profitable in Benin. Furthermore, profitability is positively correlated with education, access to credit, extension services, soil quality, amount of fertilizer and herbicide applied, and ownership of mobile phone. Policy reforms needed to sustain the development of irrigation and to increase profits include the development of irrigation policy document, the reinforcement of institutional supports for farmers, and the improvement in the production practices.
\end{abstract}

Keywords: Adoption, Irrigation, Policy, Rice, Benin

JEL: L25, Q15, Q18

\section{INTRODUCTION}

Rainfall in Benin is characterized by large spatial and temporal variations making the production of rainfed crops very uncertain. The average rainfall in Benin is between $700 \mathrm{~mm}$ and $1500 \mathrm{~mm}$ per year (Attogouinon $\boldsymbol{e t}$ al., 2017). In addition to this relative good rainfall condition, the country has significant hydro-agricultural resources consisting of several water flows and valleys. The country has four (4) major hydrographic units, namely: the hydrographic units of Niger, Volta, Ouémé, and Mono. These increase the potential of irrigation in Benin. The government of Benin believes that irrigation development may contribute to improve domestic food production especially rice output. This belief led to the development of irrigation schemes throughout the country since 1960 with objective to reduce food insecurity and poverty.

Despite an increase in the total land developed for irrigated crop production from 3,932 ha in 1975 to 23,040 ha in 2008 (FAO, 2014) less than $10 \%$ of the irrigation potential in Benin is developed and the irrigation facilities are sub-optimally used. About $25 \%$ of the total area developed for irrigation purpose in Benin were unused (FAO, 2014). In the irrigation scheme of Malanville (study area) in 2015, of the 516 ha of irrigable land, 116 ha were uncropped. Similar situation is observed on the other irrigation schemes in Benin. As an example, of the 88 ha of land in the irrigation scheme of Zonmon, 51.9 ha were unused. In the irrigation scheme of Bamè, of the 33 ha of irrigable land, 20.5 ha were uncropped. Better situation seems to be observed in the irrigation scheme of Koussin-lélé where of the 120 ha of land, only 8.2 ha were unused.
Majority of the irrigation schemes developed in Benin have failed upon the withdrawal of foreign partners in 1980s. This was due notably to the lack of producers' involvement in the management process and the lack of technical expertise required for the development of irrigation practices (MAEP, 2009a). With regard to this, the main research question is, what policy can facilitate farmers' adoption of irrigation and improve profitability without repeating the past and current failures? The present study aims to provide policy for improving farmers' adoption of irrigation and profitability in Benin. The specific objectives are: (1) to estimate the profitability of irrigated rice production, (2) to assess factors that influence the profitability of irrigated rice production, and (3) to discuss policy needed to improve profitability of irrigated rice production.

This study complements previous studies in Benin by Totin et al. (2012) and Djagba et al. (2014) but is more focused on the policy issues for increasing participation to irrigation and profitability in the country. The analysis in this study is based on the survey of 150 irrigated rice farmers from the irrigation scheme of Malanville in 2015. A total of 1054 farmers were operating on the scheme and were classified in 24 groups comprising between 20 and 100 farmers. Therefore, a proportional sampling technique was used to obtain the random sample.

The rest of the paper is arranged as follows. The next section presents the history and context of irrigation development in Benin, followed by section which analyse the profitability of irrigated rice production. The following section deals with the policy option for improving use of irrigation and profitability. Final section provides the conclusion. 


\section{IRRIGATION DEVELOPMENT IN BENIN}

\section{Irrigation potential and practices in Benin}

Irrigation development in Benin is at an early stage with only a small number of smallholder farmers cultivating crops under irrigation. The irrigated crops in Benin are rice, sugar cane, vegetables, roots and tubers (MAEP, 2009a). The total irrigation potential is estimated at 322,000 ha, of which 205,900 ha is lowland and 117,000 ha account for upland that could be irrigated in the hydrographic units of Ouémé, Mono and Niger. The irrigation scheme began with small gardeners concentrated around major urban centers and large cities which produced essentially vegetables or fruits on the very small areas of a few tens or hundreds square meters. The first remarkable actions in the area dates back to the 1960s with the establishment of some irrigation schemes for various crops. These schemes have been the result of several public collaborations including the state and some of the international institute such as the World Bank (WB), the Food and Agriculture Organization (FAO), the West African Rice Development Association (WARDA), the African Development Bank (AFDB) and the Chinese technical partners.

Several irrigation systems (gravity, pump, manual watering, etc.) are used according to the financial capacity of the producers. Surface irrigation is practiced on $46 \%$ of the total area, followed by sprinkler irrigation on $42 \%$ of the total area and drip irrigation covers $12 \%$ of the total area under irrigation (FAO, 2005). Canal irrigation is used in all irrigated rice schemes in Benin whereas sprinkler irrigation and drip irrigation are mostly used for vegetable production.

\section{Management of irrigation schemes in Benin}

Several irrigation schemes were developed between 1970 and 1980. A total of 4,500 ha of lowland, valleys and streams were arranged to develop rice cultivation, vegetables, fruit crops and industrial crops (oil palm and sugar cane). The irrigation schemes were public initiatives under the control of the State with technical and financial support from the international partners. The state manages these schemes through its companies such as the Société Nationale d'Irrigation et d'Aménagement Hydro-agricole (SONIAH), the Société Béninoise de Palmier à Huile (SOBEPALH), the Société Sucrière de Savè (SSS), the Société Nationale des Fruits et Légumes (SONAFEL) which were in charge of the irrigation schemes of rice, oil palm, sugar cane and vegetables and fruits, respectively. These companies used salaried labour and occasionally hired casual labour for all agricultural operations. Very early, in its management, this operating system began to show its limits and most of the schemes have been unsubscribed. The main reason was the lack of producers' involvement in the management of these facilities (MAEP, 2009a).

Between 1980 and 1990, the schemes management status changed and the schemes were placed under the responsibility of the Regional Center for Rural Development (CARDER). Farmers who previously were working for the state companies, are now working on their own, but they have to respect the regulations under the schemes. These regulations include the respect of the environment, the payment of water fees and for other inputs and services. Again, this management system failed to meet expectation. The reason was that the farmers did not have the technical expertise required for the development of the irrigation practices (MAEP, 2009a). Hence they abandoned the production under irrigation. From the major irrigation schemes developed in the 1970s, there remains today only a few schemes, namely, the Sugar Cane Scheme of Savè and the Rice Schemes of Malanville, Koussin-lélé and Dévé (MAEP, 2009a). Since 1990, the limited results of the irrigation schemes has led the government of Benin to choose as priority the following actions for the future: (a) the promotion of small scale irrigation facilities, (b) the rehabilitation of some of these old irrigation schemes and, (c) the involvement of beneficiaries in the management process of these schemes.

On the rice irrigation scheme of Malanville, which is the biggest rice scheme in Benin, there were approximately 1054 rice farmers in 2015 classified in groups of 20 to 100 people with a total of 24 groups. Each group is led by a committee of three (3) people, and a broad committee of thirteen (13) members is in charge of managing the scheme. The committee's role is to ensure the provision of water, other inputs and services from production to the marketing of rice. At the end of each season, the producers pay back a fee of three bags of 84 $\mathrm{kg}$ of rice per plot of 0.25 ha to the committee. The committee is supposed to use a part of the fees collected to ensure the maintenance and rehabilitation of the irrigation system. But in reality, since 1990, the rehabilitation of the irrigation scheme has been the responsibility of the State that intervenes every 10 or 15 years to rehabilitate the scheme.

\section{DATA AND METHODS}

\section{Data and sampling procedure}

Data used in this study was collected in 2015 from the irrigation scheme of Malanville in Benin. The irrigation scheme of Malanville is the most important in the country in terms of size and yield. The total irrigable land under the scheme is 516 ha of which 400 ha were used in 2015. The scheme was constructed in 1970. The water used is pumped from the Niger River and distributed into the farms through surface canals. Mono-cropping is practiced with rice produced by approximately 1054 farmers operating on the scheme in 2015 . In its management, the scheme is designed to serve the five districts in the municipality of Malanville. The State is the owner of the irrigated land and irrigated land size ranges from 0.25 ha to $2 \mathrm{ha}$. The average rice yield is about $5.7 \mathrm{Mt} / \mathrm{ha}$.

Cochran's (1977) formula (Eq.1) was used to determine the sample size required for the sample to be statistically representative of the irrigation farmers' population.

$n=z^{2} * p(1-p) / m^{2}$

Where: $n$ is the required sample size; $z$ is the confidence level at $95 \%$ (standard value is 1.96); $p$ is the estimated prevalence of rice farmers using irrigation; and $m$ is the 
margin of error at $5 \%$. Using the above formula, a sample size of 126 is obtained. However, for oversampling 150 irrigation farmers were finally selected for the survey. To select these farmers we used a proportional sampling technique based on a list provided by the committee in charge of the management of the irrigation scheme. This sampling technique helps to ensure a fair representation of farmers as they are in groups of 20 to 100 people with a total of 24 groups operating on the scheme in 2015. Information collected concern socio-economic and demographic characteristics of farmers and production (inputs, output, prices, etc...).

\section{Analytical Framework of Profitability of Irrigated Rice Production}

The estimation of profit derived from the irrigated rice production was estimated using a farm budget analysis as expressed by the Eq. 2.

$G M=T R-\sum_{i=1}^{n} O P$

Where: $G M$ is the gross margin per hectare (ha), $T R$ the total revenue per ha calculated as the product of the total quantity of rice output (in number of bags) and the price of a bag. $O P$ is the operating costs including the costs of seeds, labour, fertilizer, herbicide, equipment (hoe, cutlass among others), and irrigation water fees.

Multiple regression analysis was done to determine factors that influence profitability of irrigated rice production. The farm profit is considered as a linear function of the socio-economic and demographic characteristics of the farmers as well as institutional variables. The estimated regression model is presented as follows:

$Y_{i}=\beta X_{i}+\mu_{i}$

Where: $\mathrm{Y}_{i}$ represents profit, $\beta$ is a vector of parameters to be estimated, $\mu$ the error term. $X_{i}$ is the vector of explanatory variables including age, gender, education, access to credit, extension services, membership of farmers based organization (FBO), engagement in off farm activities, perceived soil quality, quantity of fertilizer applied, quantity of herbicide applied, quantity of seed applied, ownership of mobile phone and access to media. Table 1 presents definition, measurement and expected signs of the variables used in the regression model.

\section{RESULTS AND DISCUSSION}

\section{Profitability of irrigated rice production}

The results are presented in Table 2. The average total revenue per hectare for irrigated rice production was estimated at CFA 904,577 while the total production cost per ha was CFA 416,285. This clearly shows a positive gross margin estimated at CFA 488, 292 per ha. With regard to high profitability from irrigated rice production, the importance given to investment in irrigation development in Benin was justified.
Table 1: Definition and measurement of explanatory variables and expected signs

\begin{tabular}{|c|c|c|}
\hline Variables & Measurement & $\begin{array}{l}\text { Expected } \\
\text { signs }\end{array}$ \\
\hline Age & Number of years & $+/-$ \\
\hline Gender & $\begin{array}{l}\text { Binary }(1=\text { male, } 0= \\
\text { female) }\end{array}$ & $+/-$ \\
\hline Education & $\begin{array}{l}\text { Binary ( } 1 \text { if educated, } \\
0=\text { otherwise) }\end{array}$ & + \\
\hline Access to credit & $\begin{array}{l}\text { Binary }(1=\text { Yes, } 0= \\
\text { No) }\end{array}$ & + \\
\hline $\begin{array}{l}\text { Extension } \\
\text { services }\end{array}$ & $\begin{array}{l}\text { Binary }(1=\text { Yes, } 0= \\
\text { No) }\end{array}$ & + \\
\hline $\begin{array}{l}\text { FBO } \\
\text { membership }\end{array}$ & $\begin{array}{l}\text { Binary }(1=\text { Yes, } 0= \\
\text { No) }\end{array}$ & + \\
\hline $\begin{array}{l}\text { Off farm } \\
\text { activities }\end{array}$ & $\begin{array}{l}\text { Binary }(1=\text { Yes, } 0= \\
\text { No) }\end{array}$ & + \\
\hline Soil quality & $\begin{array}{l}\text { Binary }(1=\text { fertile, } 0= \\
\text { otherwise) }\end{array}$ & + \\
\hline $\begin{array}{l}\text { Quantity of } \\
\text { fertilizer } \\
\text { applied }\end{array}$ & $\mathrm{Kg} / \mathrm{ha}$ & + \\
\hline $\begin{array}{l}\text { Quantity of } \\
\text { herbicide } \\
\text { applied }\end{array}$ & $\mathrm{Kg} / \mathrm{ha}$ & + \\
\hline $\begin{array}{l}\text { Quantity of } \\
\text { seed applied }\end{array}$ & $\mathrm{Kg} / \mathrm{ha}$ & + \\
\hline $\begin{array}{l}\text { Ownership of } \\
\text { mobile phone }\end{array}$ & $\begin{array}{l}\text { Binary }(1=\text { Yes, } 0= \\
\text { No) }\end{array}$ & + \\
\hline $\begin{array}{l}\text { Access to } \\
\text { media }\end{array}$ & $\begin{array}{l}\text { Binary ( } 1=\text { if farmer } \\
\text { has radio or } \mathrm{TV}, 0= \\
\text { otherwise) }\end{array}$ & + \\
\hline
\end{tabular}

Table 2: Profitability of rice production on the irrigation scheme of Malanville

\begin{tabular}{lr}
\hline Items cost per hectare & Irrigation farming \\
\hline Seed & 12,990 \\
Labour & 110,078 \\
Fertilizer & 61,360 \\
Herbicide & 12,834 \\
Agricultural equipment & 50,469 \\
Irrigation water fees & 168,000 \\
Transaction cost & 554 \\
Total cost per hectare & 416,285 \\
Total revenue per hectare & 904,577 \\
Gross Margin per hectare & 488,292 \\
\hline
\end{tabular}

Note: All items are in CFA franc which is Benin currency. At the time of survey USD 1= CFA 591.25

The disaggregation analysis of the profit across some socio-economics and institutional characteristics of the farmers revealed significant differences (Table 3 ). It is observed that female farmers have higher profit per ha compared to male farmers. Educated farmers have higher farm profit than the non-educated farmers. This is in line with the idea that education improves farmers' ability to change farming practices and to adopt a new technology to enhance farm production (Duraisamy, 2002; Adeoti, 2009; Nonvide, 2017). Farmers that were engaged in off farm activity have higher profit than those who did not. Involvement in off farm activity is an additional source of 
income for the farmers. The off farm income may be reinvested to increase farm production (Nonvide, 2017) and thus to improve profitability. Institutional factors associated with increased farm profitability include extension services and credit. Farmers that had access to extension services have significantly higher profit compared to those who did not. This suggests that regular contact with extension agents contributes to increase farm profit. The extension agents can provide support to farmers in term of agronomic practices and new technologies aimed to increase farm productivity. They can also help in linking farmers to market (both inputs and output markets). It is also observed significant difference in profit between farmers that had received credit and those who did not. This suggests that access to credit is likely to increase farmer's profit from rice production. It enables farmers to purchase farm inputs in time (Mdemu et al., 2017).

Table 3: Difference in profit across farmers' characteristics

\begin{tabular}{lll}
\hline Variables & Profit & t-test \\
\hline Gender & & \\
Male & 462,430 & \\
Female & 596,205 & \\
Difference & 133,776 & $2.39 * *$ \\
Marital status & & \\
Married & 480,544 & \\
unmarried & 520,622 & \\
Difference & 40,078 & 0.70 \\
Education & & \\
Non educated & 336,718 & \\
Educated & 715,655 & \\
Difference & $-378,937$ & $-11.22 * * *$ \\
Extension services & & \\
Yes & 283,267 & \\
No & 501,380 & \\
Difference & $-218,113$ & $-2.34 * *$ \\
Access to credit & & \\
Yes & 536,935 & \\
No & 315,834 & \\
Difference & $-221,101$ & $-4.31 * * *$ \\
Off farm activities & & \\
Yes & 529,333 & \\
No & 406,212 & \\
Difference & $-123,121$ & $-2.63 * * *$ \\
\hline Note: *** p 0.01; ** p <0.05 & \\
& & \\
& &
\end{tabular}

The results of the regression model are reported in Table 4. The model has a good fit with its explanatory variables as indicated by the significance of the F-statistic. The results show that the explanatory variables together explain $72 \%$ of the total variation in the profitability of irrigated rice production. Variables such as education, access to credit, extension services, soil quality, quantity of fertilizer and herbicide applied, and ownership of mobile phone were found to be significant determinants of the profitability of irrigated rice production.

The coefficient of the education dummy is significant and positively correlated with irrigated rice profitability. This implies that educated farmers have higher profit compared to non-educated. In regard to the literature this could be explained by the fact educated farers have more ability to access information which could enable them in making better farm management decision (Adeoti, 2009; Dang, 2017). We also found that access to credit has a positive and significant effect on profit, implying that farmers that have access to credit have higher credit compared to those who did not. This result is in line with Hyuha et al. (2007). With credit farmers could purchase fertilizers, herbicides and other inputs which could support production, improve crop revenue and profitability. Access to extension services has a positive effect on irrigated rice profitability. This suggests that farmers that have contact with extension agents were found to have higher profit than those who did not. Access to extension services is key to improve farmers' knowledge on agronomic practices which could enable them to increase production. This result agrees with previous findings by Haq (2012) in Bangladesh and Antwi and Aborisade (2017) in Ghana who found rice farmers' access to extension services reduces yield losses and improves profitability.

Table 4: Determinants of profitability of irrigated rice production

\begin{tabular}{|c|c|c|c|}
\hline $\begin{array}{l}\text { Dependent } \\
\text { variable: Ln profit }\end{array}$ & Coefficient & $\begin{array}{l}\text { Robust } \\
\text { std. error }\end{array}$ & $\begin{array}{l}\mathrm{P}- \\
\text { value }\end{array}$ \\
\hline Age (in years) & 0.008 & 0.006 & 0.181 \\
\hline Gender $($ male $=1)$ & 0.041 & 0.130 & 0.751 \\
\hline $\begin{array}{l}\text { Education } \\
\text { (educated =1) }\end{array}$ & $0.168 *$ & 0.097 & 0.088 \\
\hline $\begin{array}{l}\text { Access to credit } \\
(\text { yes }=1)\end{array}$ & $0.998 * * *$ & 0.189 & 0.000 \\
\hline $\begin{array}{l}\text { Extension services } \\
(\text { yes }=1)\end{array}$ & $0.841 *$ & 0.460 & 0.070 \\
\hline $\begin{array}{l}\text { FBO membership } \\
(\text { yes }=1)\end{array}$ & -0.349 & 0.567 & 0.539 \\
\hline $\begin{array}{l}\text { Off farm activities } \\
\text { (yes =1) }\end{array}$ & 0.099 & 0.102 & 0.332 \\
\hline $\begin{array}{l}\text { Soil quality (fertile } \\
=1 \text { ) }\end{array}$ & $0.280 * * *$ & 0.105 & 0.008 \\
\hline $\begin{array}{l}\text { Quantity of } \\
\text { fertilizer applied } \\
(\mathrm{kg} / \mathrm{ha})\end{array}$ & $0.002 *$ & 0.001 & 0.075 \\
\hline $\begin{array}{l}\text { Quantity of } \\
\text { herbicide applied } \\
\text { (L/ha) }\end{array}$ & $0.087 * *$ & 0.041 & 0.039 \\
\hline $\begin{array}{l}\text { Quantity of seed } \\
\text { applied (kg/ha) }\end{array}$ & -0.005 & 0.003 & 0.121 \\
\hline $\begin{array}{l}\text { Ownership of } \\
\text { mobile phone (yes } \\
=1 \text { ) }\end{array}$ & $0.265 * * *$ & 0.085 & 0.002 \\
\hline $\begin{array}{l}\text { Access to media ( } 1 \\
\text { if radio or } \mathrm{TV} \text { ) }\end{array}$ & 0.130 & 0.177 & 0.464 \\
\hline Constance & $1.261 *$ & 0.731 & 0.087 \\
\hline \multicolumn{4}{|c|}{$\mathrm{R}^{2}=0.72 ; \quad \mathrm{F}(13,136)=17.42 ;$ Prob $>\mathrm{F}=0.0000$} \\
\hline
\end{tabular}

The quality of the soil is also an important determinant of profitability. This variable has a positive and significant effect on irrigated rice profitability, implying that farmers that perceived their soil as fertile have higher profit compared to the other. As expected the amount of fertilizer 
and herbicide applied has positive and significant effect on rice profitability. This implies that rice profitability increases with increase in inputs application. Our results suggest that farm production intensification is key for improving profitability. Finally, we found that ownership of mobile phone is important determinant of rice profitability. Farmers that own mobile phone have higher profit compared to those who did not. This suggests that agricultural information could be shared trough mobile phone. Mittal and Tripathi (2009) argue that mobile phone could be a catalyst to improving agricultural productivity and income if the shared information has the following characteristics: quality, timeliness and trustworthiness.

\section{Discussion}

Over four decades, government, private sector enterprises, technical and financial partners have invested in the development of irrigation with the purpose to intensify food crop production and improve returns to rural farmers in Benin. This study has shown that profitability of irrigated rice production depends on farmers' socioeconomic characteristics, institutional variables and farm production factors such as education, access to credit, extension services, soil quality, quantity of fertilizer and herbicide applied, and ownership of mobile phone. These variables must be considered in designing policy for the development of irrigation in Benin. In the following, three categories of policies to improving farmers' adoption of irrigation and profitability are discussed: irrigation policy; institutional support measures; and production policy.

\section{Irrigation Policy}

Due to the lack of producers' involvement in the management of the scheme and the lack of technical expertise required for the sustainable development of the irrigation scheme, farmers abandoned the production of rice under irrigation, and most of the scheme have been unsubscribed after the withdrawal of the Chinese and Taiwanese technical partnership. To benefit from the important investment in irrigation without repeating the past actions, and achieve sustainable development of small scale irrigation, it is important to reduce external investments as much as possible and increase farmers' capacity to manage the scheme (Sakaki and Koga, 2013; Bjornlund et al., 2017).

Farmers on the irrigation scheme of Malanville reported that the water fees are high, and this is the main factor handicapping the use of irrigation. This situation may be due to the fact that there was no metric of measuring the amount of water used by each farmer. The water fees paid depends on the size of their land. This provides no incentive for water conservation (Mwamakamba et al., 2017). The water fees represent about $18 \%$ of the total output per hectare. Thus, efforts should be made to reduce these fees for the farmers. Also there is a need to find a way to measure the amount of water used by a farmer in order to set water price equivalent to the real amount of water used. This may contribute to the efficiency use of the water regarding the new challenge of climate change and variability and may benefit others water users.
Although the Strategic Plan to Revitalize Agricultural Sector (PSRSA) in Benin and the rice policy contain some guideline for developing irrigation in Benin, the country does not have any policy document for irrigation development. Therefore, it is important, for sustainable development of irrigation sector in the country, to develop a policy document for irrigation. This document should clearly provide the vision of the country for the development of irrigation and state the strategies that will help in the achievement of the vision. As shown by Totin et al. (2012) an unclear division of responsibilities between local farmer groups and the government for canal maintenance and a lack of effective local rules for the distribution and maintenance of irrigation infrastructure are factors affecting the successful development of irrigation in Benin. The irrigation policy document should also propose the necessary incentives that may facilitate the adoption of irrigation as many of the irrigation schemes in Benin are sub-optimally used.

\section{Reinforcing institutional support for farmers}

The findings reveal that profitability of irrigated rice production depends on institutional factors such as education, extension services and access to credit. Therefore, institutional support should be enhanced. Farmers could be educated through regular training on agronomic practices and other information needed to improve rice production and profitability. Farmers need strong assistance from the extension agents. Regular contact with extension agents may help them to have information on new technology, availability of farminputs and market information. Extension services is a channel of transferring the skills and knowledge needed for increasing productivity and profitability (Wheeler $\boldsymbol{e t} \boldsymbol{a l}$., 2017). There are no adequate credit systems and the few rural banks in place are not willing or not able to provide sufficient loan for the farmers. Most of the rice farmers were obliged to turn to local traders in order to get loans despite the high interest rate. As reported by the farmers they paid back sometimes an interest rate of $100 \%$. Therefore, there is a need to provide credit facilities for the farmers. Mdemu et al. (2017) argued that lack of credit is the central cause of majority of the constraints faced by smallholder farmers. Lack of credit prevents farmers from timely access to farm technologies resulting in delaying in farm operations (Bjornlund and Pittock, 2017).

Farmers in the irrigation scheme of Malanville sell mostly their rice at the farm gate to the State which is the major buyer of rice in the municipality of Malanville. The state buys the rice from the farmers and paid them back later. As most of the farmers are in need of cash, that situation does not provide incentives for them. Also, in the year where the state fails or delays in buying the rice, the situation becomes critical for the farmers. Farmers who were able to sell their rice in the urban markets or to the exporters from the neighbouring countries (Niger, Nigeria and Togo) had higher return despite increased transaction costs. Farmers need information on the price of rice and on the existing market for rice sale. This would enable them to make more informed decision. A good communication mechanism should be put in place to improve information sharing. In this regard, government 
or agricultural development institutions could help making these information available to farmers. This may be done through radio, television, or mobile phone application since $75 \%$ of farmers have radio or television and $73 \%$ own mobile phone.

\section{Production practices}

The rice yield from the irrigation scheme of Malanville (5.7 metric tonnes per ha) is still below the potential yield (8- 10 metric tonnes per ha) that can be achieved in Benin (MAEP, 2009b). This is due to the low use of inputs. While the development of irrigation scheme is often accompanied with provision of farm inputs (seed, fertilizer, herbicide, among others), many farmers tend to use lower than recommended rate. For instance, only 46 $\%$, and $39 \%$ of the surveyed farmers had observed the recommended rate for fertilizer and herbicide application respectively. Discussions with farmers suggest that this is due to the high cost of obtaining inputs. Although the management committee of the scheme provide farmers with the necessary inputs, the farmers reported that due to lack of finance, they made in kind payment for the inputs. For instance, a farmer who received $50 \mathrm{~kg}$ of fertilizer may paid back at the end of the season $50 \mathrm{~kg}$ of paddy rice. This is often costly for farmers. Inputs policy reforms are needed to promote easy access to production inputs and increase the use level of inputs in order to optimize productivity and profits. A set of institutional support measures should reinforce the link among credit, inputs and output. Extension agents should play an important role in training farmers on the right usage and benefit of applying recommended rate of inputs.

About $11 \%$ of farmers used tractor. This low level of tractor use may be due to the small land allocated to irrigation farmers discouraging investment in mechanization to increase productivity and profits. It is therefore essential to expand irrigated land and facilitate access to mechanization. Other important aspect of the production is the crop choice. This is essential for the viability of small-scale irrigation schemes (Bjornlund $\boldsymbol{e t}$ al., 2017). Since the establishment of the irrigation schemes of Malanville in 1970, rice is the only crop grown on the scheme. This may lead to poor soil quality and thus to decreasing crop yield. Therefore, there is a need for crop rotation policy to improve crop yield. Crop rotation is essential in sustainable agricultural system as it plays a crucial role in farming by keeping pests and diseases under control, and provides enough nutrients to different crops, and maintain soil quality (Nel and Loubser, 2004; Filizadeh et al., 2007).

\section{CONCLUSION}

The expectation of the development of irrigation in Benin is to enhance food security and reduce poverty. However, past investments in irrigation development were unsuccessful. This study provides policy to support governments' actions to sustain small scale irrigation schemes in Benin. Case study from the irrigation scheme of Malanville is used to estimate profitability of irrigated rice production and to detail policy needed to improve adoption and profitability of irrigation in Benin. Results reveal that irrigated rice production is profitable in Benin, and depend on variables such as education, access to credit, extension services, soil quality, quantity of fertilizer and herbicide applied, and ownership of mobile phone. Three categories of policies identified to sustain the development of irrigation schemes in Benin are the irrigation policy, the reinforcement of institutional supports for farmers, and the production practices.

\section{Acknowledgments}

We thank the anonymous reviewers for their helpful comments and suggestions. Special thanks to Dr. Yves Coffi Zanmassou for his comments on the first version of the paper. We also thank farmers from the irrigation scheme of Malanville in Benin for their collaboration during the data collection.

\section{REFERENCES}

ADEOTI, I A. (2009). Factors Influencing Irrigation Technology Adoption and its Impact on Household Poverty in Ghana. Journal of Agriculture and Rural Development in the Tropics and Subtropics, 109 (1), p.5163.

https://www.jarts.info/index.php/jarts/article/view/73/66. ANTWI, K. D. and ABORISADE, O. (2017). Profitability of Rice Production among Small-Scale Rice Producers in Ghana. American Journal of Agricultural Science, 4 (1), p. 13-17. http://www.aascit.org/journal/ajas.

ATTOGOUINON, A., LAWIN, A.E., M'PO, Y. N. and HOUNGUE, R. (2017). Extreme Precipitation Indices Trend Assessment over the Upper Oueme River Valley(Benin). Hydrology, 4 (3), p. 36. DOI: 10.3390/hydrology4030036.

BJORNLUND, H. and PITTOCK, J. (2017). Exploring the productivity and profitability of small-scale communal irrigation systems in Sub-Saharan Africa, International Journal of Water Resources Development, 33 (5), 685689. DOI: 10.1080/07900627.2017.1326881.

BJORNLUND, H., ROOYEN, A. and STIRZAKER, R (2017). Profitability and productivity barriers and opportunities in small-scale irrigation schemes. International Journal of Water Resources Development, 33 (5), p. 690-704. DOI: 10.1080/07900627.2016.1263552.

COCHRAN, W. G. (1977). Sampling techniques (3rd ed.). New York: John Wiley \& Sons.

DANG, N. H. (2017). Profitability and Profit Efficiency of Rice Farming in Tra Vinh Province, Vietnam. Review of Integrative Business and Economics Research, 6 (s1), p. 191-201.

DJAGBA, J. F., RODENBURG, J., ZWART, S. J., HOUNDAGBA, C. J. and KIEPE, P. (2014). Failure and success factors of irrigation system developments: A case study from the Ouémé and Zou valleys In Benin. Irrigation and Drainage, 63, p.328-339. DOI: 10.1002/ird.1794.

DURAISAMY, P. (2002). Changes in returns to education in India, 1983-94: by gender, age-cohort and location', Economics of Education Review, 21, P. 609-622. DOI: 10.1016/S0272-7757(01)00047-4. 
FAO. (2014). Statistical database (FAOSTAT). Rome: Food and Agriculture Organization.

FAO. (2005). Irrigation in Africa in figures. AQUASTAT Survey, 2005. Land and Water Development Division, FAO, Rome.

FILIZADEH, Y., REZAZADEH, A. and YOUNESSI, Z. (2007). Effects of Crop Rotation and Tillage Depth on Weed Competition and Yield of Rice in the Paddy Fields of Northern Iran. Journal of Agricultural Sciences and Technologies, 9: 99-105. http://jastold.modares.ac.ir/article_4460_e6b61246e535211af4711 c59986f8774.pdf.

HAQ, A. Z. M. (2012). Agricultural Extension Contact in Bangladesh. Journal of Agricultural Informatics, 3 (2), p. 29-36. http://real.mtak.hu/23914/1/95 375_1_PB_u.pdf HYUHA, T. S., BASHAASHA, B., NKONYA, E. and KRAYBILL, D. (2007). Analysis of profit inefficiency in rice production in Eastern and Northern Uganda. African Crop Science Journal, 15 (4), p. 243 - 253. https://www.ajol.info/index.php/acsj/article/view/54465.

MAEP. (2009a). Projet de renforcement des capacités nationales de suivi des ressources en eau axe sur la gestion de l'eau agricole. Cotonou, Benin.

MAEP. (2009b). Fiche technique sur la culture du riz au Bénin. Cotonou, Benin.

MDEMU, M. V., MZIRAY, N., BJORNLUND, H., and KASHAIGILI, J. J. (2017). Barriers to and opportunities for improving productivity and profitability of the Kiwere and Magozi irrigation schemes in Tanzania. International Journal of Water Resources Development, 33 (5), 725739. DOI: $10.1080 / 07900627.2016 .1188267$.

MITTAL, S. and TRIPATHI, G. (2009). Role of Mobile Phone Technology in Improving Small Farm Productivity. Agricultural Economics Research Review, 22, p. 451-459. https://econpapers.repec.org/article/agsaerrae/57502.htm.
MWAMAKAMBA, S. N., SIBANDA, L. M., PITTOCK, J., STIRZAKER, R., BJORNLUND, H., VAN ROOYEN A., MUNGUAMBE, P., MDEMU, M. V. and KASHAIGILI, J. J. (2017). Irrigating Africa: Policy barriers and opportunities for enhanced productivity of smallholder farmers. International Journal of Water Resources Development, 33 (5), p. 824-838. DOI: 10.1080/07900627.2017.1321531.

NEL, A. A. and LOUBSER, H. L. (2004). The impact of crop rotation on profitability and production risk in the eastern and north western Free State. Agrekon, 43 (1), p. 101- 111. DOI: $10.1080 / 03031853.2004 .9523638$.

NONVIDE, G. M. A. (2017). Effect of Adoption of Irrigation on Rice Yield in the Municipality of Malanville, Benin. African Development Review, 29 (2), p. 109-120. DOI: $10.1111 / 1467-8268.12266$.

SAKAKI, M., and KOGA, K. (2013). An effective approach to sustainable small-scale irrigation developments in Sub-Saharan Africa. Paddy Water Environment, 11, p. 1-14. DOI: 10.1007/s10333-0110287-X.

TOTIN, E., VAN MIERLO, B., SAÏDOU, A., MONGBO, R., AGBOSSOU, E., STROOSNIJDER, L., and LEEUWIS C. (2012). Barriers and opportunities for innovation in rice production in the inland valleys of Benin. NJAS-Wageningen Journal of Life Sciences, 6063, p. 57-66. DOI: 10.1016/j.njas.2012.06.001.

WHEELER, S. A., ZUO, A., BJORNLUND, H., MDEMU, M. V., VAN ROOYEN, A. and MUNGUAMBE, P. (2017). An overview of extension use in irrigated agriculture and case studies in South-Eastern Africa. International Journal of Water Resources Development, 33 (5), p. 755-769. DOI: 10.1080/07900627.2016.1225570. 